\title{
Hypertension and cholesterol
}

1. Centro Universitário Lusíada (UNILUS), Santos, SP, Brasil. 2. Universidade Estadual do Piauí (UESPI), Teresina, PI, Brasil.

Cardiovascular aggravators result from a series of factors that may be related among themselves or metabolically connected; thus, these may contribute to and determine the onset of future diseases that may affect the functioning of the heart, such as arterial hypertension (SAH) ${ }^{1}$. SAH is frequent in developing and developed countries, and the number of occurrences increases with age ${ }^{2}$. There are, in Brasil, 250,000 deaths per year due to cardiovascular diseases, and SAH is one of the causes in approximately $50 \%$ of them $^{3}$. Studies show that its occurrence is between $52 \%$ and $63 \%$, which makes it possible for SAH to be considered a public health problem that considerably increases the cardiovascular risk of patients in these cases $^{1,4-6}$.

Clinical trials for the management of hypertension show the importance of controlling blood pressure (BP) as a means of reducing the risks of cardiovascular diseases ${ }^{3}$. A review study that included eight trials and more than 15,000 individuals aged 60 years or older indicated that the use of antihypertensive agents reduced stroke by $30 \%$, coronary heart disease by $23 \%$, and mortality by $13 \%$. Patients with SAH have obesity, elevated heart rate, diabetes mellitus, and high cholesterol levels. SAH alone is found in only $13 \%$ of men and $20 \%$ of women ${ }^{7}$. This shows the importance of detecting, controlling, and treating other aggravating factors, if present, early.
SAH is characterized by several functional and structural changes in the plasma membrane, which are constantly related to changes in metabolism, such as high blood triglycerides, low levels of HDL, and high levels of LDL $^{8}$. The elevation of viscosity in the plasmalemma that occurs in high-pressure carriers shows changes in lipid composition ${ }^{9}$. In cases of high levels of triglycerides and high levels of cholesterol, there is a great transition between the lipids present in the blood and those present in the plasma membranes, which leads to a decrease in the fluidity of the membranes and a change in the transport of ions ${ }^{8}$. An increased supply of cholesterol to plasma membranes was associated with decreased sodium and potassium pump function, reduced sodium efflux, and increased intracellular sodium affinity ${ }^{10,11}$. The decrease in plasma membrane cholesterol has increased the rate at which sodium and potassium pump ions are transported ${ }^{12,13}$. Similarly, the decrease of plasma membrane cholesterol in erythrocytes led to increased sodium efflux and decreased intracellular sodium ${ }^{14}$. The latter may be considered beneficial since the reduction in the sodium levels present inside the cells is an alternative for the prevention and treatment of cardiovascular diseases ${ }^{15}$.

Studies show that in people without pre-existing cardiovascular diseases, the use of statins in patients with high lipid levels leads to a reduction in cholesterol 
levels with a consequently reduced occurrence of cardiovascular diseases ${ }^{16}$. In Brasil, there has been an increase in the consumption of processed and industrialized foods in recent years, with a reduction in the consumption of healthy foods such as vegetables and legumes $^{17,18}$. This contributes to the elevation of the levels of saturated fat, trans fat, and sugar consumed, leading to an increase in cholesterol levels ${ }^{19,20}$, which is associated with diets with high sodium content, which in turn accentuates the increase in BP, thus contributing to the increase of chances of developing hypertension. Thus, it is important to raise the population's awareness of the need to have a healthy diet, since food can determine the emergence of new diseases and comorbidities that, associated or not with other pre-existing factors, can lead to a decrease in health and quality of life.

Work conducted in the city of São Paulo, both authors (Rubens Moura Campos Zeron and Victor Campos de Albuquerque) participated in the reference search, drafting, and revision of the paper.

\section{REFERENCES}

1. Marte AP, Santos RD. Bases fisiopatológicas da dislipidemia e hipertensão arterial. Rev Bras Hipertens. 2007;14(4):252-7.

2. Chobanian AV, Bakris GL, Black HR, Cushman WC, Green LA, Izzo |L |r, et al; National Heart, Lung, and Blood Institute Joint National Committee on Prevention, Detection, Evaluation, and Treatment of High Blood Pressure; National High Blood Pressure Education Program Coordinating Committee. The Seventh Report of the Joint National Committee on Prevention, Detection, Evaluation, and Treatment of High Blood Pressure: the INC 7 report. JAMA. 2003;289(19):2560-72.

3. Miranda RD, Perrotti TC, Bellinazzi VR, Nóbrega TM, Cendoroglo MS, Toniolo Neto J. Hipertensão arterial no idoso: peculiaridades na fisiopatologia, no diagnóstico e no tratamento. Rev Bras Hipertens. 2002;9(3):293-300.

4. Oliveira SMJV, Santos JLF, Lebrão ML, Duarte YAO, Pierin AMG. Hipertensão arterial referida em mulheres idosas: prevalência e fatores associados. Rev Text Context Enferm. 2008;17(2):241-9.

5. Jobim EFC, Cabrera MAS. Prevalência de hipertensão arterial em idosos atendidos no programa da saúde da família em Jardim Alegre, PR. Rev Envelhec Saúde. 2007;13(2).

6. Jobim EFC. Hipertensão arterial no idoso: classificação e peculiaridades Rev Bras Clin Med. 2008:6:250-3.

7. Rudnichi A, Safar M, Asmar R, Guize L, Benetos A. Prevalence of cardiovascular risk factors in a French population. J Hypertens Suppl. 1998;16(1):S85-90

8. Dominiczak AF, Davidson AO, Bohr DF. Plasma membrane in hypertension: microviscosity and calcium stabilization. Hypertens Res. 1994;17(2):79-86.

9. Yeagle PL. Lipid regulation of cell membrane structure and function. FASEB J. 1989;3(7):1833-42.

10. Lijnen $P$, Petrov V. Cholesterol modulation of transmembrane cation transport systems in human erythrocytes. Biochem Mol Med. 1995;56(1):52-62.
11. Levy R, Hevroni D, Cabantchik ZI, Livne A. Lii-Nao countertransport and Li leak in erythrocytes are differential7y affected by membrane enrichment with cholestetyl hemisuccinate. Biochim Biophys Acta. 1986;854(2):325-8.

12. Giraud F, Claret M, Garay R. Interactions of cholesterol with the Na pump in red blood cells. Nature. 1976;264(5587):646-8.

13. Claret M, Garay R, Giraud F. The effect of membrane cholesterol on the sodium pump in red blood cells. J Physiol. 1978;274:247-63.

14. Lijnen $P$, Celis H, Fagard R, Staessen I, Amery A. Influence of cholesterol lowering on plasma membrane lipids and cationic transport systems. J Hypertens. 1994;12(1):59-64.

15. Medina AJ, Pinilla OA, Portiansky EL, Caldiz Cl, Ennis IL. Silencing of the $\mathrm{Na}^{+} / \mathrm{H}^{+}$exchanger $1(\mathrm{NHE}-1)$ prevents cardiac structural and functional remodeling induced by angiotensin II. Exp Mol Pathol. 2019;107:1-9.

16. Yusuf S, Bosch J, Dagenais G, Zhu J, Xavier D, Liu L; HOPE-3 Investigators. Cholesterol lowering in intermediate-risk persons without cardiovascular disease. N Engl | Med. 2016;374(21):2021-31.

17. World Health Organization. Integrated prevention of noncommunicable diseases: global strategy on diet, physical activity and health. Geneva: World Health Organization; 2004.

18. Levy-Costa RB, Sichieri R, Pontes NS, Monteiro CA. Disponibilidade domiciliar de alimentos no Brasil: distribuição e evolução (1974-2003). Rev Saude Publica [Internet]. 2005;39(4):530-40.

19. Willett WC. Surprising news about fat. In: Willett WC, ed. Eat, drink and be healthy: the Harvard Medical School guide to healthy eating. New York: Simon \& Schuster Adult Publishing Group; 2001. p.56-84.

20. Ascherio A, Katan MB, Zock PL, Stampfer MI, Willett WC. Trans fatty acids and coronary heart disease. N Engl J Med. 1999;340(25):1994-8. 